\title{
Pengaruh Good Government Governance, Pengendalian Intern, dan Budaya Organisasi Terhadap Kinerja Organisasi Perangkat Daerah (OPD)
}

\author{
I Gede Iswara Yudhasena ${ }^{1}$ \\ IG. A. M. Asri Dwija Putri² \\ ${ }^{1,2}$ Fakultas Ekonomi dan Bisnis, Universitas Udayana (Unud), Bali, Indonesia \\ e-mail:iswarayudhasena@gmail.com
}

\begin{abstract}
ABSTRAK
Organisasi Perangkat Daerah (OPD) Kabupaten Karangasem perlu memerhatikan penerapan prinsip-prinsip Good Government Governance (GGG), pengendalian intern dan budaya organisasi untuk meningkatkan kinerja organisasi perangkat daerah (OPD). Penelitian ini bertujuan untuk memperoleh bukti empiris pengaruh GGG, pengendalian intern dan budaya organisasi terhadap kinerja organisasi perangkat daerah (OPD) di Kabupaten Karangasem. Metode pengumpulan data dalam penelitian ini adalah metode survey dengan menggunakanteknik kuesioner. Metode penentuan sampel menggunakan teknik sampling jenuh. Sampel yang digunakan berjumlah 3 orangpegawai di setiap organisasi perangkat daerah (OPD) yang total jumlah yang ada 32 (OPD). Teknik analisis yang digunakan dalam penelitian ini adalah analisis regresi linier berganda. Hasil penelitian ini menunjukkan bahwa pengaruh GGG, pengendalian intern dan budaya organisasi berpengaruh positif terhadap kinerja organisasi perangkat daerah (OPD) di Kabupaten Karangasem.

Kata kunci: Good Government Governance, pengendalian intern, budaya organisasi,

KinerjaOrganisasi Perangkat Daerah (OPD).
\end{abstract}

\begin{abstract}
The Regional Devices Organization (OPD) of Karangasem Regency needs to pay attention to the application of the principles of Good Government Governance (GGG), internal control and organizational culture to improve regional organizational performance (OPD). This study aims to obtain empirical evidence of the effect of $G G G$, internal control and organizational culture on regional organizational performance (OPD) in Karangasem Regency. The method of data collection in this study is the survey method using questionnaire techniques. The sampling method uses a saturated sampling technique. The sample used amounted to 3 employees in each regional device organization (OPD) with a total number of 32 (OPD). The analysis technique used in this study is multiple linear regression analysis. The results of this study indicate that the effect of $G G G$, internal control and organizational culture has a positive effect on the performance of regional organizational organizations $(O P D)$ in Karangasem Regency.
\end{abstract}

Keywords: Good Government Governance, internal control, organizational culture, Regional Organizational Performance (OPD).

\section{PENDAHULUAN}

Peran seorangpegawai sangat penting yang membantu dalam perkembangan instansi, jika telah melaksanakan tugas-tugasnya dengan baik dan benar maka hal tersebut akan berpengaruh terhadap kinerja dari organisasi..Secara umum, kinerja 
Organisasi Perangkat Daerah (OPD)diyakini dipengaruhi olehgood government governance,pengendalian intern dan budaya organisasi dari Organisasi Perangkat Daerah (OPD)itu sendiri,pada akhirnya kinerja tersebut akan berdampak pada kinerja Organisasi Perangkat Daerah (OPD).Menurut pendapat (Ambarwati, 2013) menyatakan bahwa organisasi yang menerapkan praktek good government governance telah berupaya meminimalkan risiko keputusan yang salah atau yang menguntungkan diri sendiri, sehingga meningkatkan kinerja pemerintahan.Sehingga dapat memajukan pemerintahan Kabupaten Banyumas.

Good Government Governance memiliki prinsip-prinsip tata kelola pemerintahan yang baik yaitu partisipasi masyarakat, tegaknya supremasi hukum, transparansi, peduli pada stakeholder, berorientasi pada konsensus, kesetaraan, efektifitas dan efisiensi, akuntanbilitas dan visi strategis. Selain itu menurut (Aisyah \& Safitri, 2014) menyebutkan bahwa dengan melaksanakan good government governance, salah satu manfaat yang bisa dipetik adalah meningkatkan kinerja melalui tercapainya proses pengambilan keputusan yang lebih baik, meningkatkan efisiensi operasional serta lebih meningkatkan pelayanan kepada publik.Penelitian tentang good government governancememberikan bukti empiris bahwa variabel good government governancemerupakan faktor penting yang berpengaruh terhadap kinerja Organisasi Perangkat Daerah (OPD) (Setyawan dan Dwija Putri, 2013). Dengan demikian, ada pengaruh pelaksanaan prinsip-prinsip good government governance terhadap efektivitas kerja Organisasi Perangkat Daerah (OPD). 
Hal lain yang mempengaruhi kinerjaOrganisasi Perangkat Daerah (OPD) adalah pengendalian intern.Pengendalian intern akuntansi yang berfungsi untuk mengatur teknik akuntansi seperti perubahan dalam pendekatan sistem akuntansi dan prosedur pencatatan, dokumen dan formulir yang digunakan, fungsi-fungsi otorisasi untuk tujuan pengendalian intern, laporan serta pengawasan. Pengendalian intern merupakan hal yang mempengaruhi kualitas laporan keuangan (Sari, 2014). Fungsi pengendalian intern tersebut dapat membantu sumber daya manusia untuk mengetahui batasan-batasan dan hak-hak dalam bekerja serta teknologi informasi seperti apa yang bisa dimanfaatkan untuk membantu pekerjaannya tersebut. Dengan pengendalian intern yang baik maka pemerintah akan dapat menghasilkan laporan keuangan yang berkualitas.

Budaya organisasi atau (budaya kerja) ialah keyakinan semua anggota organisasi akan sistem nilai-nilai serta yang diterapkan, dikembangkan, serta dipelajari secara berkesinambungan, bermanfaat sebagai sistem perekatdan dapat dijadikan sebagai acuan berperilaku dalam organisasi guna mencapai tujuan organisasi yang telah ditetapkan Temaja, (2016), Louisa, Obi, and Adigwe (2014) menyatakan bahwa budaya organisasi menggambarkan keadaan organisasi yang sesungguhnya dari sebuah organisasi. Budaya yang produktif adalah budaya yang dapat menjadikan organisasi menjadi kuat dan tujuan organisasi dapat tercapai.Dengan demikian budaya organisasi baik secara langsung maupun tidak langsung akan berpengaruh terhadap kinerja organisasi.

Robbins (2010:64) menyatakan bahwa kekuatan budaya akan menghasilkan kinerja organisasi yang baik, karena dianggap bahwa budaya yang 
kuat adalah budaya yang menanamkan nilai-nilai utama secara kokoh dan diterima secara luas di kalangan paraOrganisasi Perangkat Daerah (OPD).Peran budaya adalah untuk dapat mengintegrasikan lingkungan internal dan beradaptasi dengan lingkungan eksternal dan secara internal budaya organisasi harus selaras dengan strategi, struktur, teknologi, sistem dan nilai-nilai individu dari anggota organisasi(Pratami, 2018).Menurut Barney, Mansor dan Tayib (2010), budaya organisasi merupakan satu set kompleks keyakinan, asumsi, nilai dan simbolsimbol yang digunakan dalam menentukan jalan dimana organisasi melakukan pekerjaan dan tugas.Budaya organisasi penting bagi setiap organisasi,karena merupakan kebiasaan-kebiasaan yang terjadi dalam hirarki organisasi yang mewakili norma-norma perilaku yang diikuti oleh para anggota organisasi (Dzulkifli, 2013).Maryana (2011) memandang budaya organisasi juga dapat menjadi suatu instrumen keunggulan kompetitif utama, yaitu bila budaya organisasi mendukung strategi organisasidan bila budaya organisasi dapat menjawab atau mengatasi tantangan lingkungan dengan cepat dan tepat.Oleh karena itu dapat dikatakan bahwa budaya organisasi dapat mempengaruhi perilaku individu dan kelompok dalam organisasi.

Robbins (2006:123) menyatakan bahwa budaya merupakan sebuah sistem pemaknaan bersama dibentuk oleh warganya yang sekaligus menjadi pembeda dengan organisasi lain. Jika makin banyak anggota yang menerima nilai-nilai inti organisasi, menyetujui jajaran tingkatkepentingannya dan merasa sangat terikat kepada organisasi tersebut, maka makin kuat budaya organisasi tersebut. Oleh karna itu budaya organisasi sangat penting bahwa dapat memengaruhi kinerja 
organisasi perangkat daerah (OPD). Seperti penelitian sebelumnya yang melibatkan variabel budaya organisasi yaitu padapenelitian (Tripambudi, 2014), Asfar (2009) dan Pratama (2012) yang menunjukkan hasil yang serupa bahwa budaya organisasi memiliki pengaruh yang sangat signifikan terhadap kinerjaOrganisasi Perangkat Daerah (OPD).

Tujuan Penelitian ini adalah untuk mengetahui pengaruh penerapan good governmentgovernance, pengendalian intern, budaya organisasi terhadap kinerjaOrganisasi Perangkat Daerah (OPD).Teori utama yang terkait dengangoodgovernment governance adalah teori agensi. Teoriagency theory yang dikembangkan oleh Jensen and Meckling (1976)memandang bahwa manajemen sebagai agentbagi para pemegang saham, akan bertindak dengan penuh kesadaran bagi kepentingannya sendiri, bukan sebagai pihak yang arif dan bijaksana serta adil terhadap pemegang saham. Dalam agency theory dan sesuai dengan prinsip utama untuk mewujudkan good government governance, terdapat beberapa komponen penting salah satunya yaitu transparasi dan akuntabilitas. Akuntabilitas laporan keuangan yang merupakan tanggung jawab mengenai integritas keuangan pengangkatan dan ketaatan terhadap peraturan perundang-undangan.

Efektifitas yang harus dicapai bukan hanya berupa output akan tetapi yang lebih penting adalah efektifitas dari sudut pandang outcome. Ujiantho dan Pramuka (2007) menyatakan adanya informasi yang tidak simetris tersebut dapat mendorong manajemen (agen) untuk menyembunyikan beberapa informasi yang tidak diketahui oleh pemilik (prinsipal) hal itu dilakukan untuk memaksimalkan keuntungan agen.Agen dapat termotivasi untuk melaporkan informasi yang tidak 
sebenarnya kepada prinsipal, terutama jika informasi tersebut berkaitan dengan pengukuran kinerja agen.

Permasalahan keagenan yang terjadi di dalam instansi pemerintahandapat diatasi dengan diterapkannya good governmentgovernance (GGG). GGG dalam hal ini berperan penting dimana pengelolaan pemerintahan harus diawasi dan dikendalikan untuk memastikan bahwa pengelolaan organisasi dilakukan dengankepatuhan atas berbagai peraturan dan ketentuan yang berlaku.

Dalam hal ini pemerintahberfungsi sebagai agen yang diberi kewenangan untuk melaksanakan kewajiban tertentu yang ditentukan oleh para pengguna informasi keuangan pemerintah sebagai principal, naik secara langsung atau tidak langsung melalui wakil-wakilnya. Dalam hubungan keagenan, pemerintah sebagai agen harusmelaksanakan apa yang menjadi kepentingan para pengguna informasi keuanganpemerintah sebagai suatu hubungan keagenan (Rosalin, 2011).

Teori stewardship adalah teori yang menggambarkan situasi dimana para manjer tidaklah termotivasi oleh tujuan-tujuan individu tetapi lebih ditunjukan pada sasaran hasil utama mereka untuk kepentingan organisasi, sehingga teori ini mempunyai dasar psikologi dan sosiologi yang telah dirancang dimana para eksekutif sebagai steward termotivasi untuk bertindak sesuai keinginan prinsipal, selain itu perilaku steward tidak akan meninggalkan organisasinya sebab steward berusaha mencapaisasaran organisasinya. Pada Stewardship Theory, model of man ini didasarkan pada pelayan yang memiliki perilaku dimana dia dapat dibentuk agar selalu dapat diajak bekerjasama dalam organisasi, memiliki perilaku kolektif 
atau berkelompok dengan utilitas tinggi dari pada individunya dan selalu bersedia untuk melayani.

GGG adalah tata cara mengelola urusan-urusan publik yang baik (Mardiasmo, 2002:17). Pratolo (2010) menganalisis peran GGG yang mana hasil penelitiannya mengungkapkan bahwa prinsip-prinsip GGG, yakni: transparansi, akuntabilitas, pertanggungjawaban, independensi, dan keadilan memengaruhi kinerja pemerintah daerah.Hubungan tidak langsung pada kepuasan masyarakat melalui kinerja pemerintahadalah prinsip-prinsip GGG, yakni variabel transparansi, pertanggungjawaban dan keadilan. Hasil temuan penelitian lainnya terkait penerapan GGG yang memengaruhi kinerja dilakukan oleh (Zeyn, 2011) dan (Azlim, 2012).

Good government governance menjadi konsep yang diajukan dengan tujuan untuk meningkatkan kinerja organisasi perangkat daerah (OPD) melalui monitoring kinerja pemerintah, serta menjamin akuntabilitas pemerintah terhadap stakeholder dengan didasarkan pada kerangka peraturandemi tercapainya pengelolaan instansi yang lebih transparan.Bila konsep ini diterapkan dengan baik maka diharapkan pertumbuhan ekonomi akan terus menanjak seiring dengan transparansi pengelolaan instansi yang makin baik dan nantinya akan menguntungkan banyak pihak (Nasution dan Setiawan, 2007). Seluruh aktivitasaktivitas operasional instansi akan berjalan dengan baik apabila pelaksanaan good governmentgovernancedapat berjalan dengan efektif, maka hal tersebut dapatberdampak terhadap kinerja instansi secara finansial maupun nonfinansial yang juga akan turut membaik(Brown dan Caylor, 2004). 
I Gede Iswara Yudhasena dan IG. A. M. Asri Dwija Putri. Pengaruh ...

Sistem pengendalian intern menurut Peraturan Pemerintah Republik Indonesia Nomor 60 tahun 2008 yaitu proses yang integral pada tindakan dankegiatan yang dialakukan secara terus menerus oleh pimpinan dan seluruhpegawai untuk memberikan keyakinan memadai atas tercapainya tujuanorganisasi melalui kegiatan yang efektif dan efisien, keandalan laporan keuangan, pengamanan aset negara dan ketaatan terhadap peraturan perundangundangan. Pengendalian intern pemerintah dilaksanakan oleh Badan Pengawas Keuangan (BPK).

Budaya organisasi sebagai unit sosial, yang terdiri dari sekelompok orang yang berinteraksi untuk mencapai tujuan bersama, serta terdiri dari orang-orang dengan latar belakang sosial ekonomi, budaya dan motivasi yang berbeda menimbulkan benturan nilai-nilai individual dalam proses keorganisasian dan dapat menjadi salah satu faktor pengganggu upaya pencapaian tujuan organisasi.Namun demikian, budaya organisasi memiliki sejumlah disemsi yang berguna untuk memudahkan setiap upaya pengidentifikasian karakteristik budaya tertentu dalam organisasi.

Kinerja merupakan istilah yang berasal dari kata Job Performance atau Actual Performance (prestasi kerja atau prestasi sesungguhnya dicapai seseorang). Kinerja atau (prestasi kerja) adalahhasil kerja secara kualitas dan kuantitas yang dicapai seorang dalam melaksanakan tugasnya sesuai dengan tanggung jawab yang diberikan kepadanya (Mangkunegara, 2005:9). 


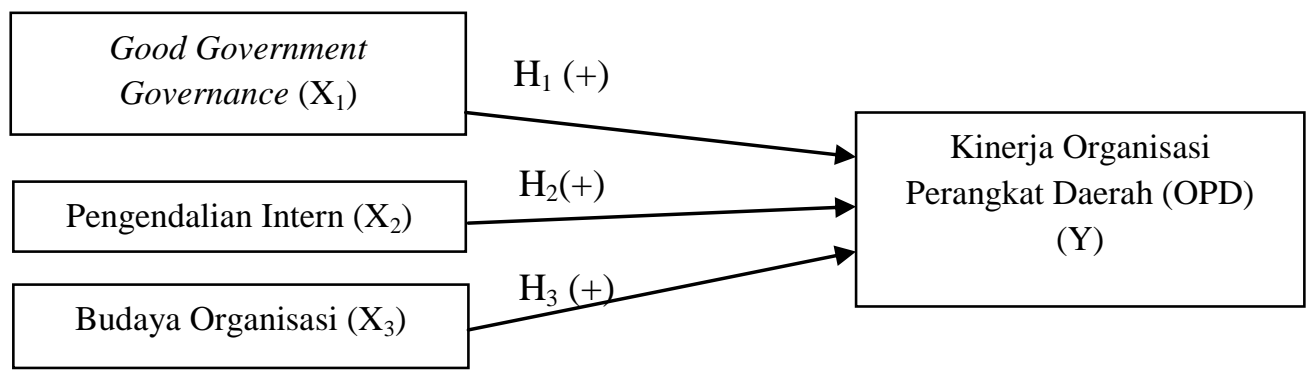

Sumber: Data terolah, 2019

Good government governance diartikan sebagai tata kelola pemerintahan yang baik pada suatu organisasi yang dilandasi oleh etika profesional dalam berkerjaatau berkarya. Di era sekarang ini banyak masyarakat yang sudah pandai dalam menilai kinerja aparatur pemerintahan, masyarakat meminta semua kinerja aparatur pemerintahan benar-benar dilakukan secara transparan dan bertanggungjawab sehingga meningkatkan kinerja aparatur pemerintahan. Hal tersebut sejalan dengan penelitian Fauziah (2016)analisis pengaruh prinsip-prinsip good government governance terhadap kinerja aparatur pemerintah (studi empiris pada Satuan Kerja Perangkat Daerah Kota Surakarta). Hasil penelitian tersebut menunjukan bahwa prinsip-prinsip good government governance yang diproksikan dengan akuntabilitas, transparansi, partisipasi, kemandiriandan pertanggungjawaban berpengaruh positif terhadap kinerja pegawai. Hal ini sejalan dengan penelitian yang dilakukan oleh Febriani (2016)mengenai pengaruh good government governance terhadap kinerja pegawai PT Pos Indonesia (Persero) Tuban Jawa Timur dan Hindistari (2015) mengenai pengaruh penerapan prinsipprinsip good government governance pada kinerja BPR Kabupaten Gianyar.Berdasarkan uraian dan hasil penelitian sebelumnya, maka hipotesis yang diajukan adalah 
I Gede Iswara Yudhasena dan IG. A. M. Asri Dwija Putri. Pengaruh ...

$\mathrm{H}_{1}$ : Good Government Governance berpengaruh positif terhadap kinerja Organisasi Perangkat Daerah (OPD) di Kabupaten Karangasem.

Pengendalian intern merupakan suatu proses yang dipengaruhi untuk memberikan jaminan yang meyakinkan bahwa tujuan organisasi dapat dicapai melalui : efisiensi dan efektivitas operasi, penyajian laporan keuangan yang dapat dipercaya, ketaatan terhadap undang-undang dan aturan yang berlaku (COSO).Dalam (Nurillah, 2014)membuktikan secara empiris bahwa sistem pengendalian internal memiliki pengaruh signifikan terhadap kualitas laporan keuangan pemerintah daerah. Halini didukung oleh penelitian yang dilakukan oleh (Sugandi, 2013) bahwa sistempengendalian internal memiliki pengaruh signifikan terhadap keterangan dalam laporan keuangan pemerintah daerah. Penelitian (Yosefrinaldi, 2013) menemukan hasilbahwa sistem pengendalian intern pemerintah berpengaruh positif terhadapkualitas laporan keuangan pemerintah daerah. Hasil penelitian ditunjukkan oleh (Setiyawati, 2013) bahwa sistem pengendalian intern berpengaruh positif terhadap kualitas laporan keuangan pemerintah daerah, sedangkan(Karmila, 2012) menyatakan bahwa sistem pengendalian intern berpengaruhsignifikan terhadap keterandalan pelaporan keuangan. Berdasarkan uraian dan hasil penelitian sebelumnya, maka hipotesis yang diajukan adalah:

$\mathrm{H}_{2}$ :Pengendalian intern berpengaruh positif terhadap kinerja Organisasi Perangkat Daerah (OPD) di Kabupaten Karangasem.

Budaya organisasi menjadi acuan bersama diantara manusia dalam melakukan interaksi dan organisasi.Penelitian yang dilakukan oleh (Abdullah dan Herlin, 2010) yang meneliti tentang pengaruh budaya organisasi, komitmen 
organisasi dan akuntabilitas publik terhadap kinerja organisasi membuktikan pengaruh budaya organisasi mempunyai hubungan yang signifikan terhadap kinerja organisasi melalui akuntabilitas publik sebagai variabel intervening.

$\mathrm{H}_{3}$ : Budayaorganisasi berpengaruh positif terhadap kinerja Organisasi Perangkat Daerah (OPD) di Kabupaten Karangasem.

\section{METODE PENELITIAN}

Penelitian ini menggunakan pendekatan kuantitatif yang bersifat asosiatif. Penelitian ini menjelaskan pengaruh good government governance, pengendalian intern dan budaya organisasi terhadap kinerjaOrganisasi Perangkat Daerah (OPD).Penelitian ini dilakukan pada Organisasi Perangkat Daerah (OPD) Kabupaten Karangasem namun kecamatan dan kelurahan tidak diikutsertakan.Obyek penelitian dalam penelitian ini adalah pengaruh good government governance, pengendalian intern dan budaya organisasi terhadap kinerjaOrganisasi Perangkat Daerah (OPD).

Variabel bebas (independent variabel) sering disebut sebagai variabel stimulus, prediktor, antecedent. Variabel bebas dalam penelitian ini adalah yang terdiri dari good government governance $\left(\mathrm{X}_{1}\right)$ pengendalian intern $\left(\mathrm{X}_{2}\right)$ dan budaya organisasi $\left(\mathrm{X}_{3}\right)$.Variabel terikat (dependent variabel) sering disebut variabel output, kriteria, dan konsekuen. Variabel terikat (Y) dalam penelitian ini adalah kinerjaOrganisasi Perangkat Daerah (OPD) di Kabupaten Karangasem.

Penelitian ini menggunakan data kualitatif berupa namaOperasional Perangkat Daerah (OPD)KabupatenKarangasem.Penelitian ini menggunakan data kuantitatif yaitu jumlah pegawai di bagian keuangan Operasional Perangkat Daerah (OPD)dan hasil kuisioner yang merupakan jawaban responden yang 
diukur dengan skala likert.Berdasarkan sumbernya, data yang digunakan dalam penelitian ini adalah data primer yang digunakan dalam penelitian ini adalah jawaban yang diberikan oleh reponden atas kuisioner penelitian.Data sekunder yang digunakan dalam penelitian ini berupa daftar Organisasi Perangkat Daerah (OPD) Kabupaten Karangasem.Kuesioner yang digunakan dalam penelitian ini digunakan untuk mengukur variabel good government governance,pengendalian intern, budaya organisasi dan kinerja Organisasi Perangkat Daerah (OPD) yang diadopsi dari penelitian Putri (2017).

Populasi dalam penelitian ini adalah pegawai bagian keuangan di Organisasi Perangkat Daerah Kabupaten Karangasem yang tergolong aktif. Metode penentuan sampel yang digunakan dalam penelitian ini adalah teknik sampling jenuh. Oleh sebab itu penelitian ini mengambil jumlah sampel sebanyak 3 (tiga) pegawai. Adapun yang menjadi kriteria responden dalampenelitian adalah kepala bagian keuangan dan dua staf pegawai bagian keuanganyang bekerja pada Organisasi Perangkat Daerah (OPD)di Kabupaten Karangasem.

Uji hipotesis dalam penelitian ini menggunakan analisis regresi linear berganda, analisis regresi linear berganda digunakan untuk meneliti pengaruh variabel bebas terhadap variabel terikat serta menunjukkan arah hubungan variabel-variabel tersebut. Berdasarkan pembahasan teori, data penelitian,variabel-variabel penelitian dan penelitian terdahulu maka bentuk persamaanregresi linear berganda penelitian ini adalah sebagai berikut.

$Y=\alpha+\beta_{1} X_{1}+\beta_{2} X_{2}+\beta_{3} X_{3}+\beta_{4} X_{4}+e$ 
Keterangan :

\begin{tabular}{|c|c|}
\hline$X_{\mathrm{I}}$ & $=$ Good Government Governance \\
\hline $\mathrm{X}_{2}$ & $=$ Pengendalian Intern \\
\hline$X_{3}$ & $=$ Budaya Organisasi \\
\hline $\mathrm{Y}$ & $=$ Kinerja Organisasi Perangkat Daerah $(\mathrm{OPD})$ \\
\hline$\alpha$ & $=$ Konstanta \\
\hline$\beta_{1}, \beta_{2}, \beta_{3}, \beta_{4}, \beta_{5}$ & $\begin{array}{l}=\text { Koefisien regresi untuk } \mathrm{X}_{1}, \mathrm{X}_{2}, \mathrm{X}_{3}, \mathrm{X}_{4} \\
=\text { Standar error }\end{array}$ \\
\hline
\end{tabular}

\section{HASIL DAN PEMBAHASAN}

Penelitian ini terdiri dari 32 Organisasi Perangkat Daerah (OPD) Kabupaten Karangasem, peniliti menggunakan 32 Organisasi Perangkat Daerah (OPD) Kabupaten Karangasem yang dijadikan sampel. Hal ini berkaitan dengan responden yang diteliti dalam penelitian ini yaitu pegawai kepala bagian keuangan dan dua staf pegawai bagian keuangandi masing-masing Organisasi Perangkat Daerah (OPD) Kabupaten Karangasem. Organisasi Perangkat Daerah (OPD) Kabupaten Karangasem bertujuan mewujudkan dan meningkatkan pelayanan umum kepada masyarakat dalam bidang melaksanakan pembangunan daerah, meningkatkan kesejahteraan masyarakat dan prasarana penunjang pelayanan secara optimal. 
Tabel 1.

Daftar OPD Kabupaten Karangasem

\begin{tabular}{|c|c|}
\hline No & Daftar Nama OPD Kabupaten Karangasem \\
\hline 1 & Sekretariat Daerah \\
\hline 2 & Sekretariat Dewan Perwakilan Rakyat Daerah \\
\hline 3 & Inspektorat Daerah \\
\hline 4 & Dinas Pendidikan Pemuda dan Olahraga \\
\hline 5 & Dinas Kesehatan \\
\hline 6 & Dinas Pekerjaan Umum dan Penataan Ruang \\
\hline 7 & Dinas Perumahan dan Kawasan Pemukiman \\
\hline 8 & Dinas Sosial \\
\hline 9 & Dinas Ketenagakerjaan \\
\hline 10 & Dinas Pemadam Kebakaran \\
\hline 11 & Dinas Permberdayaan Perempuan dan Perlindungan Anak \\
\hline 12 & Dinas Penegendalian Penduduk dan KB \\
\hline 13 & Dinas Ketahanan Pangan \\
\hline 14 & Dinas Lingkungan Hidup \\
\hline 15 & Dinas Kependudukan dan Catatan Sipil \\
\hline 16 & Dinas Pemberdayaan Masyarakat dan Desa \\
\hline 17 & Dinas Perhubungan \\
\hline 18 & Dinas Komunikasi dan Informatika \\
\hline 19 & Dinas Koperasi, Usaha Mikro, Kecil dan Menengah \\
\hline 20 & Dinas Kebudayaan \\
\hline 21 & Dinas Penanaman Modal dan Pelayanan terpadu \\
\hline 22 & Dinas Perpustakaan dan Kearsipan \\
\hline 23 & Dinas Pariwisata \\
\hline 24 & Dinas Perikanan \\
\hline 25 & Dinas Pertanian \\
\hline 26 & Dinas Perindustrian dan Perdagangan \\
\hline 27 & Satuan Polisi Pamong Praja \\
\hline 28 & Badan Perencanaan, Penelitian dan Pengembangan Daerah \\
\hline 29 & Badan Kepegawaian dan Pengembangan Sumber Daya Manusia \\
\hline 30 & Badan Pengelola Keuangan dan Aset Daerah \\
\hline 31 & Badan Kesatuan Bangsa, Politik dan Perlindungan Masyarakat \\
\hline 32 & Badan Penanggulangan Bencana Daerah \\
\hline
\end{tabular}

Responden yang dipilih dalam penelitian ini adalah 3 orang. Pegawai kepala bagian keuangan dan dua staf pegawai bagian keuangan di masing-masing Organisasi Perangkat Daerah (OPD) Kabupaten Karangasem yang dijadikan 
sampel. Berdasarkan kriteria yang ditetapkan maka sampel diambil sebanyak 96 orang yang berkerja di bagian keuangan dari 32 jumlah keseluruhan Organisasi Perangkat Daerah (OPD) Kabupaten Karangasem.

Tabel 2.

Ringkasan Pengiriman dan Pengembalian Kuesioner

\begin{tabular}{lll}
\hline Kuesioner & Jumlah & Persentase (\%) \\
\hline Kuesioner yang disebarkan & 96 & $100 \%$ \\
Kuesioner yang kembali & 96 & $100 \%$ \\
Kuesioner yang digunakan & 96 & $100 \%$ \\
\hline Sumber:
\end{tabular}

Sumber: Data diolah, 2019

Berdasarkan Tabel 2. dapat diketahui bahwa jumlah kuesioner yang tersebar ke responden sebanyak 96 kuesioner dan kembali sebanyak 96 kuesioner. Semua kuesioner yang kembali diisi dengan lengkap sehingga secara keseluruhan sebanyak 96 kuesioner yang dapat digunakan.

Karakteristik responden merupakan profil dari 96responden yang berpartisipasi dalam pengisian kuesioner penelitian ini, diketahui bahwa yang menjadi responden adalahpegawai kepala bagian keuangan dan dua staf pegawai bagian keuangan di masing-masing Organisasi Perangkat Daerah (OPD) Kabupaten Karangasem. Karakteristik responden dapat dilihat pada Tabel 3.

Data karakteristik responden meliputi jenis kelamin, usia, tingkat pendidikan dan masa bekerja dapat diuraikan sebagai berikut. Karakteristik responden berdasarkan jenis kelamin dapat digunakan untuk mengetahui proporsi responden laki-laki dan perempuan pada Organisasi Perangkat Daerah (OPD) Kabupaten Karangasem. Pada Tabel 3. menunjukkan bahwa jumlah responden laki-laki sebanyak 47 orang (49\%) dan jumlah responden perempuan sebanyak 49 
orang (51\%). Hal ini menunjukkan bahwa mayoritas responden adalah perempuan.

Tabel 3.

Karakteristik Responden

\begin{tabular}{|c|c|c|c|}
\hline No. & Karakteristik & Jumlah & Persentase $(\%)$ \\
\hline \multirow[t]{4}{*}{1} & Jenis Kelamin: & & \\
\hline & Pria & 47 & 49 \\
\hline & Wanita & 49 & 51 \\
\hline & Total & 96 & 100 \\
\hline \multirow[t]{8}{*}{2} & Umur: & & \\
\hline & 21-27 Tahun & 1 & 1 \\
\hline & 28-34 Tahun & 5 & 5.2 \\
\hline & 35-41 Tahun & 25 & 26.2 \\
\hline & 42-48 Tahun & 26 & 27.1 \\
\hline & 49-55 Tahun & 30 & 31.2 \\
\hline & 56-62 Tahun & 9 & 9.3 \\
\hline & Total & 96 & 100 \\
\hline \multirow[t]{7}{*}{3} & Tingkat Pendidikan: & & \\
\hline & SMA / SMK & 11 & 11.5 \\
\hline & D3 & 1 & 1 \\
\hline & S1 & 69 & 71.8 \\
\hline & S2 & 15 & 15.7 \\
\hline & S3 & - & - \\
\hline & Total & 96 & 100 \\
\hline \multirow[t]{6}{*}{4} & Pengalaman Kerja: & & \\
\hline & $<1$ tahun & - & - \\
\hline & $1-5$ tahun & 10 & 10.4 \\
\hline & $6-10$ tahun & 18 & 18.3 \\
\hline & $>10$ tahun & 68 & 70.3 \\
\hline & Total & 96 & 100 \\
\hline
\end{tabular}

Sumber: Data diolah, 2019

Karakteristik responden berdasarkan usianya digunakan untuk mengetahui rentang usia pegawai yang bekerja pada Organisasi Perangkat Daerah (OPD) Kabupaten Karangasem. Tabel 3. menunjukkan bahwa responden yang berusia 21 sampai 27 tahun sebanyak 1 orang (1\%), usia 28 sampai 34 tahun sebanyak 5 orang (5.2\%), usia 35 sampai 41 tahun sebanyak 25 orang (26.2\%), usia 42 
sampai 48 tahun sebanyak 26 orang (27.1\%), usia 49 sampai 55 tahun sebanyak 30 orang (31.2\%) dan usia 56 sampai 62 tahun sebanyak 9 orang (9.3\%). Hal ini menunjukkan bahwa mayoritas responden berusia 49 sampai 55 tahun.

Karakteristik responden berdasarkan tingkat pendidikan terakhir digunakan sebagai indikator untuk mengetahui tingkat pendidikan yang ditempuh oleh responden pada Organisasi Perangkat Daerah (OPD) Kabupaten Karangasem. Tabel 3. menunjukkan bahwa responden yang memiliki tingkat pendidikan pada jenjang SMA / SMK sebanyak 11 orang (11.5\%), pada jenjang D3 sebanyak 1 orang (1\%), pada jenjang S1 sebanyak 69 orang (71.8\%), dan responden yang memiliki pendidikan pada jenjang S2 sebanyak 15 orang (15.7\%).Hal ini menunjukkan bahwa berdasarkan tingkat pendidikan terakhir yang mendominasi adalah responden dengan tingkat pendidikan S1.

Karakteristik responden berdasarkan lama bekerja digunakan sebagai indikator untuk mengetahui pengalaman responden dalam bekerja pada Organisasi Perangkat Daerah (OPD) Kabupaten Karangasem.Tabel 3. menunjukkan bahwa sebanyak 10 orang (10.4\%) yang bekerja antara 1 sampai 5 tahun. Sebanyak 18 orang (18.3\%) yang bekerja selama 6 sampai 10 tahun, dan 68 orang $(70.3 \%)$ yang bekerja selama lebih dari 10 tahun. Hal ini menunjukkan bahwa mayoritas responden telah bekerja selama lebih dari 10 tahun.

Suatu instrumen dalam penelitian dikatakan valid apabila mampu mengukur apa yang ingin diukur. Suatu instrumen dikatakan valid apabila memiliki koefisien korelasi antara butir dengan skor total dalam instrumen 
tersebut lebih besar dari 0,30 dengan tingkat kesalahan Alpha 0,05. Tabel4.berikut menyajikan hasil uji validitas instrumen penelitian.

Tabel 4.

Rekapitulasi Hasil Uji Validitas Instrumen Penelitian

\begin{tabular}{|c|c|c|c|c|}
\hline Variabel & Indikator & Koefisien Korelasi & Sig. (2-tailed) & Keterangan \\
\hline \multirow{20}{*}{$\begin{array}{l}\text { Good Government } \\
\text { Governance }\left(\mathrm{X}_{1}\right)\end{array}$} & $\mathrm{X}_{1.1}$ & 0,740 & 0,000 & Valid \\
\hline & $\mathrm{X}_{1.2}$ & 0,613 & 0,000 & Valid \\
\hline & $\mathrm{X}_{1.3}$ & 0,703 & 0,000 & Valid \\
\hline & $\mathrm{X}_{1.4}$ & 0,834 & 0,000 & Valid \\
\hline & $\mathrm{X}_{1.5}$ & 0,710 & 0,000 & Valid \\
\hline & $\mathrm{X}_{1.6}$ & 0,537 & 0,000 & Valid \\
\hline & $\mathrm{X}_{1.7}$ & 0,679 & 0,000 & Valid \\
\hline & $\mathrm{X}_{1.8}$ & 0,762 & 0,000 & Valid \\
\hline & $\mathrm{X}_{1.9}$ & 0,721 & 0,000 & Valid \\
\hline & $\mathrm{X}_{1.10}$ & 0,721 & 0,000 & Valid \\
\hline & $\mathrm{X}_{1.11}$ & 0,824 & 0,000 & Valid \\
\hline & $\mathrm{X}_{1.12}$ & 0,827 & 0,000 & Valid \\
\hline & $\mathrm{X}_{1.13}$ & 0,557 & 0,000 & Valid \\
\hline & $\mathrm{X}_{1.14}$ & 0,820 & 0,000 & Valid \\
\hline & $\mathrm{X}_{1.15}$ & 0,842 & 0,000 & Valid \\
\hline & $\mathrm{X}_{1.16}$ & 0,491 & 0,000 & Valid \\
\hline & $\mathrm{X}_{1.17}$ & 0,664 & 0,000 & Valid \\
\hline & $\mathrm{X}_{1.18}$ & 0,801 & 0,000 & Valid \\
\hline & $\mathrm{X}_{1.19}$ & 0,716 & 0,000 & Valid \\
\hline & $\mathrm{X}_{1.20}$ & 0,783 & 0,000 & Valid \\
\hline \multirow{3}{*}{$\begin{array}{l}\text { Pengendalian Internal } \\
\qquad\left(\mathrm{X}_{2}\right)\end{array}$} & $\mathrm{X}_{2.1}$ & 0,894 & 0,000 & Valid \\
\hline & $\mathrm{X}_{2.2}$ & 0,885 & 0,000 & Valid \\
\hline & $\mathrm{X}_{2.3}$ & 0,834 & 0,000 & Valid \\
\hline \multirow{5}{*}{$\begin{array}{l}\text { Budaya Organisasi } \\
\qquad\left(\mathrm{X}_{3}\right)\end{array}$} & $\mathrm{X}_{2.4}$ & 0,925 & 0,000 & Valid \\
\hline & $X_{3.1}$ & 0,683 & 0,000 & Valid \\
\hline & $\mathrm{X}_{3.2}$ & 0,769 & 0,000 & Valid \\
\hline & $\mathrm{X}_{3.3}$ & 0,746 & 0,000 & Valid \\
\hline & $\mathrm{X}_{3.4}$ & 0,710 & 0,000 & Valid \\
\hline \multirow{4}{*}{ Kinerja Organisasi(Y) } & $\mathrm{Y}_{1}$ & 0,791 & 0,000 & Valid \\
\hline & $\mathrm{Y}_{2}$ & 0,869 & 0,000 & Valid \\
\hline & $\mathrm{Y}_{3}$ & 0,929 & 0,000 & Valid \\
\hline & $\mathrm{Y}_{4}$ & 0,813 & 0,000 & Valid \\
\hline
\end{tabular}

Sumber : Data diolah, 2019

Hasil uji validitas pada Tabel 4.menunjukkan bahwa seluruh instrumen penelitian yang digunakan untuk mengukur variabel Good Government 
Governance, Pengendalian Internal, Budaya Organisasi dan Kinerja Organisasi memiliki nilai koefisien korelasi dengan skor total seluruh item pernyataan lebih besar dari 0,30 dengan signifikansi kurang dari 0,05. Hal ini menunjukkan bahwa butir-butir pernyataan dalam instrument penelitian tersebut valid dan layak digunakan sebagai instrument penelitian

Uji Reliabilitas terhadap instrumen penelitian ini menggunakan nilai Alpha Cronbach. Rekapitulasi hasil uji reliabilitas instrumen penelitian dapat dilihat pada Tabel 5. berikut.

\section{Tabel 5.}

\section{Rekapitulasi Hasil Uji Reliabilitas Instrumen Penelitian}

\begin{tabular}{clccc}
\hline No. & \multicolumn{1}{c}{ Variabel } & Dimensi & Cronbach's Alpha & Keterangan \\
\hline \multirow{2}{*}{1} & Good Government Governance & Transparancy & 0,807 & Reliabel \\
& Accountability & 0,724 & Reliabel \\
& $\left(\mathrm{X}_{1}\right)$ & $\begin{array}{c}\text { Responsibility } \\
\text { Independency }\end{array}$ & 0,840 & Reliabel \\
& & Fairness & 0,781 & Reliabel \\
2 & Pengendalian Internal $\left(\mathrm{X}_{2}\right)$ & & 0,807 & Reliabel \\
3 & Budaya Organisasi $\left(\mathrm{X}_{3}\right)$ & & 0,943 & Reliabel \\
4 & Kinerja Organisasi $(\mathrm{Y})$ & & 0,922 & Reliabel \\
\multicolumn{2}{l}{ Sumber :Data diolah, 2019} & & & Reliabel
\end{tabular}

Hasil uji reliabilitas yang disajikan dalam Tabel5.menunjukkan bahwa seluruh instrumen penelitian memiliki koefisien Cronbach's Alpha lebih dari 0,60. Jadi dapat dinyatakan bahwa seluruh variabel telah memenuhi syarat reliabilitas atau kehandalan sehingga dapat digunakan untuk melakukan penelitian.

Uji normalitas ini bertujuan untuk mengetahui apakah residual dari model regresi yang dibuat berdistribusi normal atau tidak. Dalam penelitian ini uji normalitas dilakukan dengan menguji normalitas residual dengan menggunakan uji Kolmogorov-Smirnov. Jika probabilitas signifikansi nilai residual lebih besar dari 0,05 maka data tersebut dikatakan berdistribusi normal. 
Tabel 6.

Hasil Uji Normalitas

\begin{tabular}{lc}
\hline & Unstandardized Residual \\
\hline $\mathrm{N}$ & 96 \\
Kolmogorov-Smirnov Z & 1,139 \\
Asymp. Sig. (2-tailed) & 0,149 \\
\hline
\end{tabular}

Sumber:Data diolah, 2019

Berdasarkan hasil analisis pada Tabel 6.didapat nilai signifikansi sebesar 0,149 yang lebih dari 0,05 maka dapat disimpulkan bahwa model persamaan regresi dalam penelitian ini sudah berdistribusi normal.

Tabel 7.

Hasil Uji Multikoleniaritas

\begin{tabular}{lccc}
\hline \multicolumn{1}{c}{ Variabel } & Tolerance & VIF & Keterangan \\
\hline Good Government Governance $\left(\mathrm{X}_{1}\right)$ & 0,562 & 1,779 & Bebas multikol \\
Pengendalian Internal $\left(\mathrm{X}_{2}\right)$ & 0,609 & 1,641 & Bebas multikol \\
Budaya Organisasi $\left(\mathrm{X}_{3}\right)$ & 0,500 & 2,001 & Bebas multikol \\
\hline
\end{tabular}

Sumber: Data diolah, 2019

Berdasarkan Tabel 7. dapat dilihat bahwa nilai tolerance dan VIF dari seluruh variabel bebasyang diuji yaitu Good Government Governance, Pengendalian Internaldan Budaya Organisasi menunjukkan bahwa nilai tolerance untuk setiap variabel lebih besar dari 10\% dan nilai VIF lebih kecil dari 10 yang berarti model persamaan regresi bebas dari multikolinearitas.

Tabel 8.

Hasil Uji Heteroskedastisitas

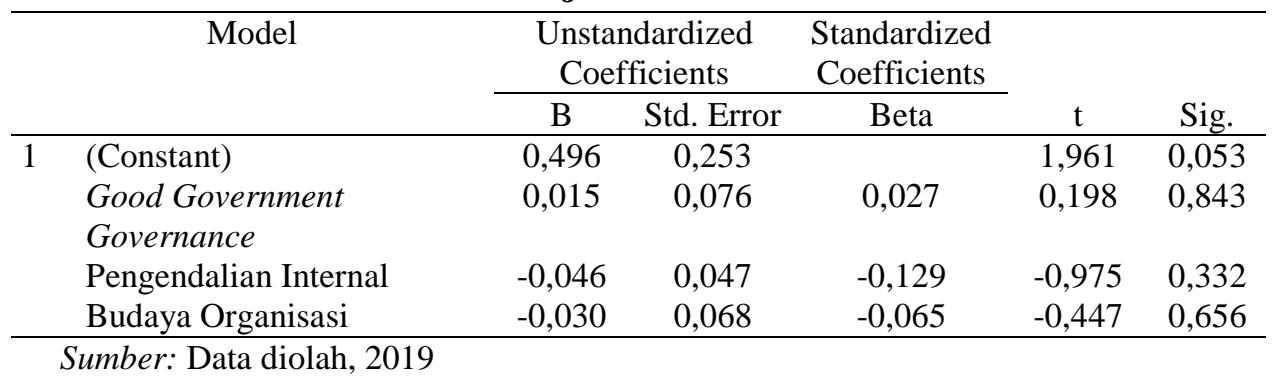

Pada Tabel 8. dapat dilihat bahwa nilai Signifikansi dari variabel Good Government Governancesebesar 0,843, nilai signifikansi variabel Pengendalian Internal sebesar 0,332 dan Budaya Organisasisebesar 0,656. Nilai tersebut lebih 
besar dari 0,05 yang berarti tidak terdapat pengaruh antara variabel bebas terhadap absolute residual. Dengan demikian, model yang dibuat tidak mengandung gejala heteroskedastisitas.

Tabel 9.

Hasil Analisis Regresi Linier Berganda

\begin{tabular}{|c|c|c|c|c|c|}
\hline \multirow[t]{2}{*}{ Variabel } & \multicolumn{2}{|c|}{$\begin{array}{l}\text { Unstandardized } \\
\text { Coefficients }\end{array}$} & \multirow{2}{*}{$\begin{array}{c}\begin{array}{c}\text { Standardized } \\
\text { Coefficients }\end{array} \\
\text { Beta }\end{array}$} & \multirow[t]{2}{*}{$\begin{array}{c}\mathrm{t} \\
\text { hitung }\end{array}$} & \multirow[t]{2}{*}{$\begin{array}{l}\text { Sig. } \\
\text { uji t }\end{array}$} \\
\hline & B & Std. Error & & & \\
\hline (Constant) & 1,039 & 0,414 & & 2,508 & 0,014 \\
\hline $\begin{array}{l}\text { Good Government Governance } \\
\left(\mathrm{X}_{1}\right)\end{array}$ & 0,273 & 0,124 & 0,224 & 2,197 & 0,031 \\
\hline Pengendalian Internal $\left(\mathrm{X}_{2}\right)$ & 0,228 & 0,077 & 0,290 & 2,964 & 0,004 \\
\hline Budaya Organisasi $\left(\mathrm{X}_{3}\right)$ & 0,292 & 0,111 & 0,284 & 2,631 & 0,010 \\
\hline R Square & 0,463 & & & & \\
\hline Adjusted R Square & 0,445 & & & & \\
\hline F Statistik & 26,421 & & & & \\
\hline Signifikansi Uji F & 0,000 & & & & \\
\hline
\end{tabular}

Berdasarkan hasil analisis regresi linier berganda seperti yang disajikan pada Tabel 9, maka dapat dibuat persamaan regresi sebagai berikut:

$$
Y=1,039+0,273 X_{1}+0,228 X_{2}+0,292 X_{3}+e
$$

Tabel 9 menunjukkan koefisien regresi padamasing-masing variabel bebas yang diuji memiliki arah koefisien yang positif dan memiliki nilai signifikansi kurang dari 0,05. Hal ini menunjukkan bahwa seluruh variabel bebas dalam penelitian ini memiliki pengaruh yang positif dan signifikan pada variabel Kinerja Organisasi Perangkat Daerah (OPD).

Konstanta $(\alpha)$ sebesar 1,039 memiliki arti apabila Good Government Governance, Pengendalian Intern dan Budaya Organisasi memiliki nilai konstan pada angka nol maka nilai Kinerja Organisasi Perangkat Daerah (OPD) akan meningkat sebesar 1,039 satuan. Koefisien regresi Good Government Governance sebesar 0,273 memiliki arti apabila Good Government Governancemeningkat satu 
satuan maka tingkat kinerja Organisasi Perangkat Daerah (OPD) meningkat sebesar 0,273 satuan dengan asumsi variabel lainnya konstan.Koefisien regresi variabel pengendalian intern sebesar 0,228 memiliki arti apabila pengendalian intern meningkat satu satuan maka kinerja Organisasi Perangkat Daerah (OPD) meningkat sebesar 0,228 satuan dengan asumsi variabel lainnya konstan.

Koefisien regresi variabel budaya organisasi sebesar 0,292 memiliki arti apabila budaya organisasi meningkat satu satuan maka kinerja Organisasi Perangkat Daerah (OPD) meningkat sebesar 0,292 satuan dengan asumsi variabel lainnya konstan.Hasil uji koefisien determinasi pada Tabel 9.menunjukkan nilai $R$ Square sebesar 0,463 mempunyai arti bahwa sebesar 46,3 persen variasi Kinerja Organisasipada Perangkat Daerah (OPD) dipengaruhi oleh variasi Good Government Governance, Pengendalian Internaldan Budaya Organisasi, sedangkan sisanya sebesar 53,7 persen dijelaskan oleh faktor lain yang tidak dimasukkan ke dalam model.

Uji kelayakan model regresi bertujuan untuk mengetahui apakah semua variabel bebas yang diidentifikasi (Good Government Governance, Pengendalian Internal dan Budaya Organisasi) tepat digunakan memprediksi Kinerja Organisasi Organisasi Perangkat Daerah (OPD). Hasil pengolahan data diperoleh nilai $\mathrm{F}_{\text {hitung }}$ sebesar 26,421 dengan signifikansi sebesar 0,000. Oleh karena nilai

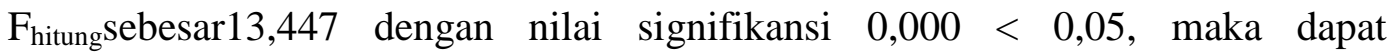
disimpulkan bahwa pada kelompok yang diuji memiliki perbedaan yang nyata (signifikan).Hasil ini mempunyai arti bahwa secara simultan Good Government 
Governance, Pengendalian Internal dan Budaya Organisasi berpengaruh signifikan terhadap Kinerja Organisasi Perangkat Daerah (OPD).

Berdasarkan hasil analisis pengaruh Good Government Governance terhadap Kinerja Organisasi Perangkat Daerah (OPD)diperoleh nilai signifikasi sebesar 0,031 dengan nilai koefisien regresi positif sebesar 0,273 Nilai Signifikansi $0,031<0,05$ mengindikasikan bahwa $\mathrm{H}_{0}$ ditolak dan $\mathrm{H}_{1}$ diterima. Hasil ini mempunyai arti bahwa Good Government Governanceberpengaruh positif dan signifikan terhadap Kinerja Organisasipada Perangkat Daerah (OPD) Kabupaten Karangasem.

Hasil penelitian ini sejalan dengan penelitianFauziah (2016)bertujuan yaitu mengetahui pengaruh penerapan prinsip-prinsip good corporate governance, motivasi dan budaya organisasi terhadap kinerja aparatur pemerintahan di Kota Surakarta.Menyatakan bahwa bahwa prinsip-prinsip good government governance, motivasi dan budaya organisasi berpengaruh terhadap kinerja organisasi perangkat daerah.Hasil penelitian ini mendukung teori keagenandisini memberikan pengertian bahwa pihak manajemen instansi yang berperan sebagai agen dan anggota yang sebagai prinsipal dalam agency relationship. Pengurus memperoleh wewenang dan kekuasaan dari kepala dinasuntukmenjalankan tugas dan wewenang yang diberikan. Atas dasar itu pengurus merumuskan berbagai kebijaksanaan yang harus dilakukan pengelola dan menjalankan tugasnya. Pengurusyang berperan sebagai agen merupakan pihak yang memperoleh mandat dari anggota sebagai prinsipal untuk menjalankan tugas mengoptimalkan pemanfaatan sumber daya yang dimiliki oleh pemerintah. 
Berdasarkan hasil analisis pengaruh Pengendalian Internal terhadap Kinerja Organisasi Perangkat Daerah (OPD) diperoleh nilai signifikansi sebesar 0,004 dengan nilai koefisien regresi yang positif sebesar 0,228. Nilai Signifikansi $0,004<0,050$, maka mengindikasikan bahwa $\mathrm{H}_{0}$ ditolak dan $\mathrm{H}_{2}$ diterima. Hasil ini mempunyai arti bahwa Pengendalian Internalberpengaruh positif dan signifikan terhadap KinerjaOrganisasi pada Perangkat Daerah (OPD).

Hasil tersebut sesuai dengan hasil penelitian yang dicapai Taufan Dharmawan, N. S. (2016) yang menyatakan hasil penelitian menunjukan bahwa penerapan sistem pengendalian internal di pemerintah Kota Bandung telah terlaksana dengan sangat baik. Selain itu, pelaksanaan kinerja aparatur Pemerintah Kota Bandung juga telah sesuai dengan prinsip good governance. Hasil penelitian juga menunjukan bahwa terdapat pengaruh positif antara implementasi sistem pengendalian internal terhadap kinerja instansi pemerintah. Sehingga $\mathrm{H}_{0}$ ditolak dan $\mathrm{H}_{2}$ diterima.

Hasil penelitian ini mendukung teori stewardship, dimana pengendalian inten sebagai steawardyang bertugas membantu pimpinan di masing-masing instansi dalam hal pengendalian intern penting untuk memiliki pengalaman kerja yang memadai. Hal ini sudah terlihat dari semua Organisasi Perangkat Daerah (OPD) yang menjadi sampel, karena pengendalian intern tersebut rata-rata memiliki pegalaman kerja di atas 2 tahun. Semakin lama pengalaman kerja seorang pengendalian intern, maka pegawai akan lebih memahami dan menguasai suatu keterampilan dalam bidang yang ditekuninya dan dapat menghasilkan 
laporan hasil pengawasan dengan lebih baik, dan semakin mudah meminimalisir kesalahan dalam penyusunan laporan.

Berdasarkan hasil analisis pengaruh Budaya Organisasi terhadap Kinerja Organisasi Perangkat Daerah (OPD) diperoleh nilai signifikansi sebesar 0,010 dengan nilai koefisien regresi positif sebesar 0,292. Nilai signifikansi 0,010 $<0,05$ mengindikasikan bahwa $\mathrm{H}_{0}$ ditolak dan $\mathrm{H}_{3}$ diterima. Hasil ini mempunyai arti bahwa Budaya Organisasi berpengaruh positif dan signifikan terhadap Kinerja Organisasi pada Perangkat Daerah (OPD).

Hasil penelitian ini sesuai dengan penelitian Mewa Hara (2016) yang menyatakan budaya organisasi mempunyai pengaruh terhadap kinerja organisasi. Untuk mengetahui komitmen organisasi mempunyai pengaruh terhadap kinerja organisasi yaitu bila budaya organisasi mendukung strategi organisasi dan bila budaya organisasi dapat menjawab atau mengatasi tantangan lingkungan dengan cepat dan tepat.Berdasarkan hasil penelitian ini budaya organisasi mempunyai pengaruh positif signifikan terhadap kinerja organisasi dan komitmen organisasi mempunyai pengaruh positif signifikan terhadap kinerja organisasi perangkat daerah (OPD).

Hasil penelitian ini mendukung teori stewardship, dimana budaya organisasi dianggap mempunyai peranan pada efektivitas instansi pemerintahan, gaya kepemimpinan yang diterapkan di Organisasi Perangkat Daerah (OPD) Kabupaten Karangasem sudah termasuk baik, dimana pimpinan instansi mampu bersikap tegas terhadap pegawainya berkaitan dengan tugas dan tangungjawab yang harus dilaksanakan oleh pegawai, selain itu pimpianan instansi juga sudah 
menyampaikan dengan jelas tujuan yang ingin dicapai ke masing-masing bagian dan pegawai serta mampu menghargai dan memberi inspirasi bagi pegawainya. Hal ini sangat baik, artinya terjalin hubungan dan komunikasi anatara pimpinan dan bawahan, karena dalam upaya meningkatkan efektivitas budaya organisasi dibutuhkan kerjasama yang kuat dari seluruh individu di instansi tersebut, baik pimpinan maupun pegawai.

Berdasarkan hasil uji dalam penelitian ini dapat diketahui bahwa kinerja organisasi perangkat daerah (OPD) tidak hanyadipengaruhi secara parsial oleh penerapan Good Government Governance melainkan adanya faktor kontijensi berupa variabel budaya organisasi yang mampu lebih meningkatkan kualitas pelayanan publik pada Organisasi Perangkat Daerah Kabupaten Karangasem.Berdasarkan hasil penelitian maka perlu diperhatikan bahwa dalam meningkatkan kualitas pelayanan publik, manajemen instansi tidak hanya mempertimbangkan penerapan Good Government Governance melainkan juga harus memerhatikan pengendalian intern dan budaya organisasi di dalam kinerja organisasi perangkat daerah (OPD) di Kabupaten Karangasem.

\section{SIMPULAN}

Berdasarkan hasil analisis penelitian, maka dapat disimpulkan bahwa Organisasi Perangkat Daerah (OPD) melakukan good government governance berpengaruh positif terhadap efektivitas kinerja Pemerintah Daerah Kabupaten Karangasem.Pengendalian Intern di Organisasi Perangkat Daerah (OPD) berpengaruh positif terhadap efektivitas kinerja Pemerintah Daerah Kabupaten 
Karangasem.Budaya Organisasi di Organisasi Perangkat Daerah (OPD) berpengaruh positif terhadap efektivitas kinerja Pemerintah Daerah Kabupaten Karangasem.

Saran dari hasil simpulan penelitian adalah Organisasi Perangkat Daerah (OPD) yang ada di Kabupaten Karangasem dimana dalam penelitian ini menggunakan sampel seluruh Organisasi Perangakat Daerah (OPD) Kabupaten Karangasem yang berjumalah 32 diharapkan terus meningkatkan efektivitas kinerjanya di Instansinya masing-masing, karena dengan adanya Good Government Governance yang efektif diharapkan dapat meminimalkan kecurangan-kecurangan yang mungkin timbul dalam suatu instansi seperti praktik korupsi, pengelolan pendapatan dan pengelolaan belanja yang tidak sesuai ketentuan, yang dapat menimbulkan kerugian bagi daerah tersebut.

Organisasi Perangkat Daerah (OPD) Kabupaten Karangasem diharapkan terus mengevaluasi kinerja pegawainya agar dapat memberikan pelayanan publik yang terbaik dan memuaskan masyarakat serta dapat meningkatkan kinerja instansi di Kabupaten Karangasem.

\section{REFERENSI}

Abdullah, A., \& Herlin. (2010). Pengaruh Budaya Organisasi, Komitmen Organisasi dan Akuntabilitas Publik Terhadap Kinerja Organisasi. Jurnal Ekonomi Dan Bisnis, 9(2).

Aisyah, S. K., \& Safitri, E. (2014). Pengaruh Good Governance, Gaya Kepemimpinan, Komitmen Organisasi dan Budaya, Organisasi Terhadap Kinerja Pemerintah Daerah. Jurnal Online Mahasiswa Fakultas Ekonomi Universitas Riau. 
Ambarwati. (2013). Analisis Pengaruh Penerapan Prinsip-Prinsip Good Corporate Governance Dan Komitmen Organisasi Terhadap Kinerja Aparatur Pemerintahan (Studi Empiris pada Instansi-Instandi dan Satuan Kerja Perangkat Daerah Kabupaten Banyumas). Jurnal SNA XV1. Universitas Jendral Soedirman.

Azlim. (2012). Pengaruh Penerapan Good Governance dan Standar Akuntansi Pemerintahan (SAP) Terhadap Kualitas Informasi Keuangan SKPD di Kota Banda Aceh. Jurnal Akuntansi Pascasarjana Universitas Syiah Kuala, 1-14.

Dzulkifli,Muhammad (2013). Pengaruh Gaya Kepemimpinan, Motivasi, Disiplin Kerja, Kompetensi, dan Budaya Organisasi Terhadap Kinerja Pegawai. Jurnal Fakultas Ekonomi Dan Bisnis Universitas Islam Negeri Syarif Hidayatullah.

Fauziah, S. (2016). Analisis Pengaruh Penerapan Prinsip-Prinsip Good Corporate Governance, Motivasi dan Budaya Organisasi terhadap Kinerja Aparatur Pemerintahan. Jurnal Fakultas Ekonomi Universitas Muhammadiyah Surakarta., 2013.

Febriani, J. I. (2016). Pengaruh Good Corporate Governance terhadap Kinerja (Studi Pada Karyawan PT Pos Indonesia (Persero) Tuban). Jurnal Administrasi Bisnis (JAB), 32(1), 82-89.

Jensen, M. C., \& Meckling, W. H. (1976). Theory of the Firm: Managerial Behavior, Agency Costs and Ownership Structure Theory of the Firm: Managerial Behavior, Agency Costs and Ownership Structure. Journal Of Financial Economics.

Karmila, (2012). Pengaruh Kapasitas Sumber Daya Manusia dan Sistem Pengendalian Intern terhadap Keterandalan Pelaporan KeuanganPemerintah Daerah (Studi Empiris Pada Pemerintah Kabupaten Riau).Jurnal Sorot. Vol. 9 No.1.

Louisa, I., Obi, U., \& Adigwe, P. (2014). Budget practices and the Nigerian Civil Service : new insights from an organisational culture perspective ., 4(10), 2835 .

Mansor, M., \& Tayib, M. (2010). An Empirical Examination Of Organisational Culture, Job Stress And Job Satisfaction Within The Indirect Tax Administration In Malaysia. Journal Of Business And Social Science, 1(1), 81-95.

Maryana, M. (2011). Pengaruh Budaya Organisasi terhadap Sistem Informasi Akuntansi dan Implikasinya pada Pengendalian Internal (Survey pada 10 KPP Badung Kanwil Jawa Barat I).Journal Akuntansi Universitas Komputer Indonesia. 
Mangkunegara, Anwar P (2005),Manajemen Sumber Daya Manusia,Cetakan Keenam, Penerbit PT. Remaja Rosdakarya, Bandung.

Mardiasmo,(2002). Akuntansi Sektor Publik. Yogyakarta: Andi.

Mewa Hara, (2016). Pengaruh Budaya Organisasi, Komitmen Organisasi, Pengendalian Intern, Motivasi, Akuntabilitas, dan Kepuasan Kerja terhadap Kinerja Organisasi Kota Surakarta.

Nasution, M., \& Setiawan, D. (2007). Pengaruh Corporate Governanceterhadap Manajemen Laba di Industri Perbankan Indonesia.Simposium Nasional Akuntansi X.

Nurillah, A. S. (2014). Pengaruh Kompetensi Sumber Daya Manusia, Penerapan Sistem Akuntansi Keuangan Daerah (SAKD), Pemanfaatan Teknologi Informasi, dan Sistem Pengendalian Intern terhadap Kualitas Laporan Keuangan Pemerintah Daerah (Studi Empiris pada SKPD Kota Depok). Jurnal Akuntansi Dan Bisnis., 1(1), 2337-3806.

Pratami, Luh Ayu Regita. (2018). Budaya Organisasi Memediasi Kualitas Penerapan Sistem Informas Akuntansi dan Kepercayaan Teknologi Informasi padaKinerja Karaywan. E-Journal Akuntansi Universitas Udayana, 22(2), h: 1032-1058.

Pratolo, Suryo. (2010). Peran Good Government GovernanceUntuk Mewujudkan Kinerja Pemerintahan Daerah dan Kepuasan Masyarakat di Era Otonomi Daerah dalam Menghadapi Tantangan Global (Studi pada Pemerintah Kabupaten dan Kota di Daerah Istimewa Yogyakarta). Simposium Riset Ekonomi IV.

Putri, IGAM Asri Dwija, I Ulupui, \& NGP Wirawati. (2017). Pengaruh GoodCorporate Governance dan Budaya Tri Hita Karana pada Kinerja Bank Perkreditan Rakyat. Jurnal Ilmiah Akuntansi dan Bisnis, 17-24.

Robbins, (2006). Prinsip-prinsip Perlaku Organisasi, Edisi Kelima, Erlangga, Jakarta h:123.

Rosalin, Faristina. (2011). Faktor-Faktor yang Mempengaruhi Keandalan dan Timeliness Pelaporan Keuangan Badan Layanan Umum (Studi Pada Blu Kota Semarang). Tesis.

Sari, Shinta Permata \& Banu Witono. (2014). Keterandalan dan Ketepatwaktuan Pelaporan Keuangan Daerah Ditinjau Dari Sumber Daya Manusia, Pengendalian Interal dan Pemanfaatan Teknologi Informasi. Seminar 
Nasional dan Call For Paper (Sancall 2014): Research Methods And Organizatinal Study. Jurnal ISN 978. Hal 41-425.

Shifa Fauzan. (2016). Analisis Pengaruh Penerapan Prinsip-Prinsip GoodCorporate Governance, Motivasi dan Budaya Organisasi terhadap Kinerja Aparatur Pemerintahan.

Stephen P. Robbins Dan Mary Coulter. (2010). Manajemen. Edisi 10. Jakarta: Erlangga H:64.

Sugandi, Joe. (2013). Pengaruh Kapasitas Sumber Daya Manusia, Pemanfaatan Teknologi Informasi, Pengendalian Intern Akuntansi, dan Komitmen Organisasi Terhadap Keterandalan Pelaporan Keuangan Pemerintah Daerah (Survei Pada SKPD se-Kabupaten Kuansing). Jurnal Akuntansi. Universitas Riau.

Setiyawati, H. (2013). The effect of Internal Accountants ' Competence , Managers 'Commitment to Organizations and the Implementation of the Internal Control System on the Quality of Financial Reporting, 2(11), 19-27.

Setyawan, K. M., \& Dwija Putri, I. G. A. M. (2013). Pengaruh Good Corporate Governance terhadap Kinerja Pegawai Lembaga Pekreditan Desa di Kecamatan Mengwi Kabupaten Badung. E-Jurnal Akuntansi Universitas Udayana, 5(3), 586-598.

Temaja, I. P. E. A. W. (2016). Pengaruh Profesionalisme, Kepribadian, Hardiness, Motivasi Kerja, dan Budaya Organisasi pada Kinerja Auditor di Kantor Akuntan Publik Provinsi Bali.

Taufan Dharmawan, N. S. (2016). Pengaruh Implementasi Sistem Pengendalian Internal terhadap Kinerja Instansi Pemerintah (Studi Kasus pada Organisasi Perangkat Daerah Pemerintah Kota Bandung). Jurnal Riset Akuntansi Dan Keuangan. Program Studi Akuntansi. Fakultas Pendidikan Ekonomi Dan Bisnis Universitas Pendidikan Indonesia, 4(1), 941-948.

Tripambudi, N. (2014). Pengaruh budaya organisasi dan struktur organisasi pada sistem informasi akuntansi dan dampaknya terhadap kualitas informasi.

Yosefrinaldi, (2013). Pengaruh Kapasitas Sumber Daya Manusia dan Pemanfaatan Teknologi Informasi terhadap Kualitas Laporan Keuangan Pemerintah Daerah Dengan Variabel Intervening Sistem Pengendalian Intern Pemerintah (Studi Empiris pada Dinas Pengelolaan dan Aset Daerah Se-Sumatra Barat).Jurnal. Vol.1, No.1. 
ISSN: 2302-8556

E-Jurnal Akuntansi

Vol.28.1.Juli (2019): 434-464

Zeyn, E. (2011). Pengaruh Penerapan Good Governance dan Standar Akuntansi Pemerintahan terhadap Akuntabilitas Keuangan, 10(1), 52-62. 